speakers, who laid stress on the decline in reading due to the cinema and the radio, as well as on the absence of æsthetic and literary standards in the home.

Others blamed the too early and the excessive specialization in the schools, a fault which the latter referred back to the universities and the increasingly high standard of attainment required by them for the award of scholarships. The 'objective' tests, consisting of one-word answers often used in the examinations for entrance to the grammar schools, were also criticized as not encouraging the teaching and practice of continuous written English in primary schools.

The vital importance of frequent practice in writing was admitted, but the burden of marking it imposed upon the teachers of English would be intolerably heavy if more practice was to be given without an increase in free periods for marking. The position would be better if all teachers, and not only those directly responsible for the teaching of English, regarded themselves as teachers of English as well as of their special subjects, and took the trouble to correct faulty English in all written work. One speaker rightly objected to the division of English into 'Science' English and 'Literary' English; the science graduate's difficulty in written expression is part of the general problem of the teaching of English to all pupils, irrespective of the forms of their later specializations.

After Dr. Evans had replied to the various points raised, Mr. Crammer summed up the discussion. It was clear, he said, (1) that there was general agreement about the necessity of all teachers, and not only the teachers of English, making the writing of English their concern, and (2) that continuous practice in writing is essential and must go on into and throughout the university course as well as throughout sehool life. It was worth considering whether in science scholarship examinations an essay and a general paper should be made compulsory and should be given considerable weight in deciding the awards. A committee representative of both schools and colleges was formed to investigate the problem further with a view to the formulation of constructive suggestions.

\section{PHYSIOLOGY AND BIOCHEMISTRY OF FATS AND LIPOIDS}

A PHYSIOLOGICAL symposium on fats, arranged by Le Centre National de la Recherche Scientifique and supported by the Rockefeller Foundation, was held in Paris during January 5-12. The meetings took place in the Department of General Physiology (Prof. G. Schaeffer) at the Sorbonne. Prof. E. F. Terroine presided.

The conference was opened with a paper by Prof. A. C. Frazer (Great Britain), who described new methods for the study of fat absorption problems, and presented the results of his investigations on the nature of the intestinal emulsifying system and hydrolysis of triglyceride. Prof. P. Desnuelles (France) reported experiments which have confirmed and extended Prof. Frazer's work on the formation of di- and mono-glycerides as endproducts of pancreatic lipolysis. Miss E. Le Breton (France) spoke of her demonstration of $\mathrm{A}$ - and B-lecithinases and cholesterol esterase in the pan- creatic juice. Its possible importance in the fat absorption mechanism was discussed. Prof. F. Verzar (Switzerland) reviewed his work on fat absorption, dealing particularly with his experiments relating the adrenal cortex to fat absorption. Prof. A. C. Frazer followed with a detailed account of the experimental work of his school on the intracellular and distributive phases of fat absorption. Prof. P. E. Verkade (Holland) gave a short paper which illustrated the inadequacy of the alleged solvent action of bile salt solutions for fatty acids. In the subsequent discussion, agreement was reached on the questions of intraluminar emulsification, the probable importance of hydrolysis, phosphorylation and the adrenal cortex in the fat absorption mechanism, and the possible occurrence of particulate absorption of fat. The extent of hydrolysis, amount of material absorbed in particulate form, the function of phosphorylation, and the nature of the influence of the adrenal gland on the fat absorption mechanism, were fully discussed.

Prof. T. Cahn (France) described investigations in dogs designed to determine the effect of muscular exercise, fasting, hyperthermia and panereatectomy on fat mobilization; and Dr. G. Clément (France) discussed the effects of unilateral denervation on fat mobilization in rats. The relationship between B-lecithinase and cholesterol esterase in the blood, and its influence in the formation of cholesterol esters, was raised by Miss E. Le Breton. Prof. M. Machebœuf (France) described his work on lipoprotein complexes in blood and gave an account of his extensive in. vestigations into the lipoid content of fractionated plasma proteins, and interesting observations on the replacement of lipoids in lipoprotein by substances of similar molecular structure. Prof. E. Chargaff (United States) gave a survey of the association between lipoids and proteins in biological systems, discussing the possible nature of the forces concerned in the construction of these complexes, with numerous illustrations from his own experiments.

Prof. A. C. Frazer presented an account of some new methods which had been developed for the studv of particulate fat in a protein environment. He described his experiments on blood fat and artificial particulate systems. He also reported X-ray diffraction studies on nerve lipoprotein which demonstrated the importance of water in lipoprotein structure, and other useful data. A lengthy discussion on all aspects of blood fat and the methods of study of lipoprotein complexes ensued. Later, Prof. E. Chargaff spoke of his work on blood coagulation, with particular reference to the part played by lipoproteins in these reactions.

Prof. K. Bernhard (Switzerland) described the biological degradation of fatty acids. With extensive references to his own work in this field, he discussed $\beta-, \omega-$ and multiple-oxidation. $H_{e}$ suggested that $\beta$-oxidation is most likely to occur under natural conditions and that ketones are mainly formed by condensation of the 2-carbon fragments split off by $\beta$-oxidation. Prof. P. Verkade discussed the relationship between the ingestion of carbohydrate and triundecylin and the excretion of undecanedioic acid in the urine in healthy human subjects. Administra. tion of carbohydrate causes an increase of dioic aciduria. The possible significance of liver glycogen in these experiments was discussed. Prof. R. H. Barnes (United States) gave a detailed account of recent work on ketogenesis. He described the various steps in the elucidation of this problem by the use of isotope-labelled materials, and put forward a new 
hypothesis to explain the anti-ketogenic action of carbohydrates. A session was also devoted to the consideration of lecithin degradation. Dr. M. Kahane (France) described his investigations into the presence of water-soluble choline esters in the blood and tissues, and Prof. J. Roche (France) gave an account of enzymological studies on the hydrolysis of phosphoryl choline and phosphoryl colamine by phosphatases. The structure and hydrolysis of egg lecithin were discussed by Prof. P. Fleury (France).

The nutritional importance of essential unsaturated fatty acids was discussed after a survey of work in this field had been given by Prof. K. Bernhard and Prof. R. H. Barnes. Miss E. Le Breton described experiments on fatty acid dehydrogenases. She described the relationship of certain vitamins and phosphorylation to the activity of these desaturases. Their possible significance in the problem of essential fatty acids was discussed.

In the concluding session, Dr. C. Paquot (France) described his work on the autoxidation of fats, and presented theoretical considerations, both on this question and on the subject of anti-oxidants. Prof. A. Chevallier (France) described apparent relationships between the oxidation and ultra-violet absorption of glycerides, and Prof. P. Dubouloz (France) spoke of his researches on anti-oxidants in relation to vitamin A. He discussed the mechanism of antioxidant action and described preliminary experiments on the physiological properties of peroxidized lipids. Prof. R. H. Barnes gave a survey of recent work carried out in the United States on anti-oxidants, and the development of oxidative rancidity in fats. He emphasized the possible importance of rancidity in biological processes.

The official business of the symposium was completed in eight days and was carried through in a most cordial atmosphere. The full proceedings, including summaries of the various discussions, will be published in due course in the Archives des Sciences Physiologiques.

\section{METABOLIC ASPECTS OF CONVALESCENCE}

\footnotetext{
$\mathrm{T}$ HE Transactions of two conferences on "Metabolic Aspects of Convalescence" referred to below* make very stimulating reading. Although they are often so specialized that possibly only those who have themselves worked in the particular fields will fully appreciate the significance of some of the questions and answers, yet the general impression left after reading them is that one has made the 'Grand Tour' and become personally acquainted with very interesting people and ideas.

With the exception of the symposium on bone metabolism (Trans. Fourteenth Meeting), the reports are more in the nature of short progress notes rather than balanced statements of experiment and interpretation. As one contributor remarks, "The data presented are of a preliminary nature and are offered in the hope that they may stimulate discussion".

- Conference on Metabolic Aspects of Convalescence. Trans. Thirteenth Meeting, Nawshon Island, Woods Hole, Mass., June 11, 1946. Pp. il +232. 2 dollars. Trans. Fourteenth Meeting, New York, Nov. 2-13, 1946. Pp. ii +190.2 .25 dollars. (Josiah Macy, Jr., Foundation, 65 Park Avenue, New York, 1947.)
}

Convalescence is concermed with the repair of injured tissues and the restoration of normal functioning so that, in effect, the study of its metabolic aspects is very similar to the general study of growth and development. The vast mass of interrelated factors - which scientific workers are only at the beginning of unravelling -is well illustrated by the wide range of subjects covered at these conferences. The reader finds himself switched from "A Comparison of the Effect of Testosterone Propionate on the Enzyme Content of the Kidney and Liver of Castrated and Normal Rats" to "Metabolic Studies before and after Operation of Chronically Ill Patients fed entirely by Vein", or from "Partition Chromatography on Paper" to "Peritoneal Lavage in Uremia". There were sixty-five reports at the thirteenth meeting and thirty-five at the fourteenth. Between them they seem to cover the ground remarkably thoroughly, and anyone whose work is concerned with any aspect of growth or development is likely to find some point of interest which may well give a new turn to his line of thought. The symposium on bone metabolism (a subject to which a large part of earlier meetings in the series has been devoted) forms a contrast to the rest of the papers. The reports presented are longer and more detailed; there is a clear exposition of contrasting hypotheses and a series of very clear photographs.

These reports pose questions rather than provide answers, but they give the impression of being full of helpful clues and well worth studying.

\section{W. Grant}

\section{FORTHCOMING EVENTS}

(Meeting marked with an asterisk * is open to the public)

Monday, April 5 FARMER' CLUB (at the Royal Empire Society, Craven Street.
Strand, London, W.C.2), at 2.30 p.m.--Dr. T. Dalling and Dr. A. W. Strand, London, W.C.2), at 2.30 p.m.
Stableforth: "Bovine Mastitis".

PHYSICAL SOCIETY, LOW-TEMPERATURE GROUP (joint meeting with the INSTITUTE OF REFRIGERATION, at the Chemical Society, Burlington House, Piccadilly, London, W.1), at 5.30 p.m.-Prof. G. Eichelberg : "Heat-Pump Problems and Industrial Realizations".

SOCTETY OF ENGINELRS (at the Geological Society of London, Burlington House, Piceadilly, London, W.1), at 5.30 p.m.-Mr. C. G. Vokes: "Filtration".

ROYAI GEOGRAPHICAI SOCIETY (at Kensington Gore, London S.W.7), at 8.15 p.m.--Mr. John Lawrence: "The Russian Land and History".

\section{Monday, April 5-Tuesday, April 6}

SocrETY OF CHEMrCaL INDUSTRY (in the Mathematics Lecture Theatre, Royal College of Science, Huxley Building, Exhibition Road, London, S.W.7).-Symposium on "Detergents, Wetting and Emulsifying Agents".

Monday, April 5

At 2.15 p.m.- “Synthetic Detergents".

Tuesday, April 6

At 2.15 p.m.- "Wetting Agents and Auxiliary Products".

\section{Tuesday, April 6}

Royal Statistical Society, Regearch Section (at the London School of Hygiene and Tropical Medicine, Keppel Street, London, W.C.1), at 5.15 p.m.-Mr. C. R. Rao: "The Utilization of Multiple Measurements in Problems of Biological Classification".

SOCIRTY OF CHBMICAL INDUSTRY, FOOD GROUP (joint meeting with the GIASGOW SEOTION and the GLASGOW AND DISTRICT SEOTION of the ROYAL INSTITUTE OF CHEMTSTRY, in the Gas Showrooms, Sauchiehall Street, Glasgow), at 2.30 p.m.-Dr. E. C. Bate-Smith : "Refrigeration in Germany"; Mr. H. J. Bunker : "War-time Production of Food Yeast in Germany" ; at 7 p.m.-Mr. J. F. Hearne : "German Albume

Royal ANThropological INstitute (at 21 Bedford Square, Iondon, W.C.1), at 5 p.m.-Mr. Leon Underwood : "African Art and it Place in Art Tradition". 